\title{
Analiza muzycznych środków wyrazu jako klucz do wykonania cyklu kolęd i pastorałek Narodziła nam się dobroć Stanisława Hadyny
}

\begin{abstract}
Streszczenie
Cykl czternastu kolęd i pastorałek Stanisława Hadyny nie należy do najbardziej znanych dzieł twórcy. Nie jest też powszechnie wiadome, że to dzieło powstało w wyniku współpracy kompozytora z dwojgiem przyjaciół, wspaniałych artystów - Kazimierza Szemiotha (poety) i Wiesława Ochmana (śpiewaka). Analiza utworów została dokonana w oparciu o specjalistyczną literaturę z zakresu muzykologii, folklorystyki i literaturoznawstwa oraz własną praktykę wokalną i dyrygencką. Celem było zbadanie możliwych inspiracji, wskazanie związku muzyki ze słowem, przedstawienie wybranych trudności wokalnych oraz całościowe spojrzenie na cykl. W badaniach posłużono się metodą monografii. Jako czynności praktyczne została zastosowana analiza materiału nutowego, tekstów źródłowych, publikacji, nagrań. Głównymi narzędziami były: wydany przez Officina Silesia w 2009 roku cykl czternastu kolęd i pastorałek Narodziła nam się dobroć Stanisława Hadyny do słów Kazimierza Szemiotha oraz płyta z 1985 roku w wykonaniu Wiesława Ochmana i Capelli Arcis Varsoviensis pod dyrekcją Marka Sewena. Dzięki analizie udowodniono, iż omawiane utwory pochodzą z głęboko zakorzenionych w kulturze polskiej tradycji i pieśni świątecznych, a ich forma świadczy o czerpaniu zarówno z dawnych, jak i współczesnych nurtów muzyki. Badania dowiodły także znaczenia tekstów, które to warunkują charakter poszczególnych części. Artykuł dowodzi, iż świadomość zastosowanych
\end{abstract}

1 Agnieszka Panas, Wydział Nauk o Edukacji, Uniwersytet w Białymstoku, Polska, e-mail: a.panas@uwb.edu.pl, ORCID ID: https://orcid.org/0000-0003-3219-2767. 
muzycznych środków wyrazów jest kluczem do poprawnego i pełnego wykonawstwa artystycznego dzieła.

\title{
Słowa kluczowe:
}

kolędy, pastorałki, Hadyna, Szemioth, Narodziła nam się dobroć

\begin{abstract}
The cycle of fourteen carols and pastorals by Stanisław Hadyna is one of the author's lesser known works. It was created as a result of cooperation between the composer and two great artists - Kazimierz Szemioth and Władysław Ochman. Analysis of the pieces has been conducted with use of specialized literature on musicology, folklore and literary studies supported by practice as a singer and choir director. The goal was to study author's possible inspirations, to underline the relationship between music and lyrics, to present selected vocal difficulties and to look at the cycle as a whole. Research has been performed with the use of the monographic method. Practical activities consisted of analyzing the score, source text, publications and recordings. Following sources were used: Narodziła nam się dobroć [Goodness was born] by Stanisław Hadyna (lyrics - Kazimierz Szemioth, Officina Silesia, 2009) and recordings of Wiesław Ochman and Capella Arcis Varsoviensis (dir. Marek Sewen, 1985). As a result, it has been proven that analyzed pieces have their origin in traditional Polish songs. Conclusions from the analysis demonstrate importance of lyrics which form a part equally important to music. In summary, awareness of means of expression used by composer is key to performance of the work.
\end{abstract}

\section{Keywords:}

carols, pastorals, Hadyna, Szemioth, Narodziła nam się dobroć [Goodness was born]

\section{WPROWADZENIE}

Stanisław Hadyna to postać niezwykła na gruncie polskiej muzyki, wokalistyki, a także literatury i pedagogiki. Chociaż zasłynął głównie jako inicjator i twórca Zespołu Pieśni i Tańca Śląsk, umniejszające byłoby ograniczenie całego dorobku do hasła, którym jest nazwa zespołu - dzieła jego życia. Zawierają się w nim jednak wszystkie zakresy kunsztu mistrza.

„Profesor Stanisław Hadyna, legenda, mało, mocarz twórczości, która wyłowiona przez Niego w śląskich wsiach i miasteczkach, pod Jego ręką stawała się sztuką najwyższej marki. Jak On to robił?” (Niedoba, 2010). 
Hadyna stworzył nowatorski sposób opracowania muzyki ludowej. Pod wpływem warsztatu i estetyki Karola Szymanowskiego wyrobił technikę opartą na modalizmach konotujących z systemem dur-moll, licznej chromatyce i obrzędowości (Podhajski, 2005). Był to styl ,jednoczący nowsze środki kompozytorskie z silnym emocjonalizmem i sugestywną melodyką" (Podhajski, 2005, s. 292-293).

Profesor komponował przede wszystkim dla regionu i dla „Śląska”, z którym był związany kulturowo, terytorialnie, mentalnie. Tworzył coś więcej niż muzykę - były to widowiska pełne ekspresji, zakorzenienia w folklorze, bogactwa muzycznego. Połączenie śpiewu, ludowego krzyku i tańca, rytmiki kroków i treści słów, orkiestry i słonecznej młodości doprowadziło do mistrzostwa (Hadyna, 1982, s. 165-170).

\section{ANALIZA CYKLU KOLĘD I PASTORAŁEK NARODZIŁA NAM SIĘ DOBROĆ}

Narodziła nam się dobroć to najbardziej rozpoznawana kolęda Stanisława Hadyny, wykonywana również przez „Śląsk”. Tym tytułem zostało też opatrzone świąteczne widowisko muzyczne, z którym zespół wykonywał trasy koncertowe (między innymi po USA w 2015 roku). Wybrane kolędy w wielogłosowych opracowaniach zostały nagrane na płycie Święta noc w 2005 roku.

Teksty cyklu Narodziła nam się dobroć determinują cały przebieg i charakter dzieła. Poeta, Kazimierz Szemioth, znając doskonale kompozytora, nawiązuje w treści do Karpętnej (rodzinne okolice Profesora), dziecinnych wspomnień, życiowych trudności, czy do góralskich zwyczajów i stron. Pod względem jakościowym jest to wyjątkowa twórczość, która poprzez piękny język, niezwykle staranną rytmizację i przedstawione historie niesie ze sobą cenną wartość artystyczną. Stworzone na tej bazie kompozycje muzyczne nie tyle podkreślają te cechy, co współtworzą ponadczasowe dzieło. Pamiętając, że Stanisław Hadyna pisał partie wokalne z przeznaczeniem dla Wiesława Ochmana (który w tym czasie był na szczycie kariery, koncertując po całym świecie), można dostrzec również wykorzystanie pełni kompozytorskiego warsztatu i doświadczenia w tworzeniu utworów dla solistów. Profesor wiedział, że ten znamienity tenor nie stawia przed nim żadnych ograniczeń emisyjnych, a wręcz otwiera wielkie możliwości pod względem warsztatu, różnorodności charakteru, tessitury i intencji.

Połączenie trzech wyjątkowych artystów, wzajemne inspiracje i pełna przyjaźni współpraca zaowocowały powstaniem niezwykłego dzieła - cyklu czternastu kolęd i pastorałek Narodziła nam się dobroć. 


\subsection{NARODZIŁA NAM SIĘ DOBROĆ}

Cykl rozpoczyna Narodziła nam się dobroć - niezwykła opowieść w andantino cantalibile (tempo umiarkowane, śpiewnie). To samo przejmują migocące pasaże, rozłożone na ósemki w metrum 4/4. Całość utrzymana jest w tonacji e-moll, jednak dzieje się to za sprawą znaków pobocznych. Dopiero w samym zakończeniu pojawia się zagęszczona i ciężka faktura, poprzez rozbudowane piony akordowe i wieńczące finał zwycięskie E-dur. Utwór ma charakter zwrotkowy. Można wyłonić dwa powtarzające się 8-taktowe fragmenty utrzymane w średnicy głosu, po czym następuje podniesienie tessitury. Przypisując pierwszemu z nich literę A, a drugiemu $\mathrm{B}$ (uwzględniając niewielkie różnice melodyczne oraz inaczej zakończony finał), możemy określić strukturę utworu formą $\mathrm{A}^{1} \mathrm{~A}^{1} \mathrm{~B}^{1} \mathrm{~A}^{2} \mathrm{~B}^{2} \mathrm{~A}^{3}$.

W każdej z części opracowane zostały dwa wersy tekstu, zaczynające się od słów „Narodziła(o) nam się...”. Gradacja w utworze następuje nie tylko przez podniesienie tessitury w partii solisty, lecz również w ubogacaniu i wzmacnianiu akompaniamentu. Podczas słów „Wielkie niebo dzwoni gwiazdą, by sumienia

Przykład 1. Narodziła nam się dobroć. Takty 21-26 (Hadyna, 2009)
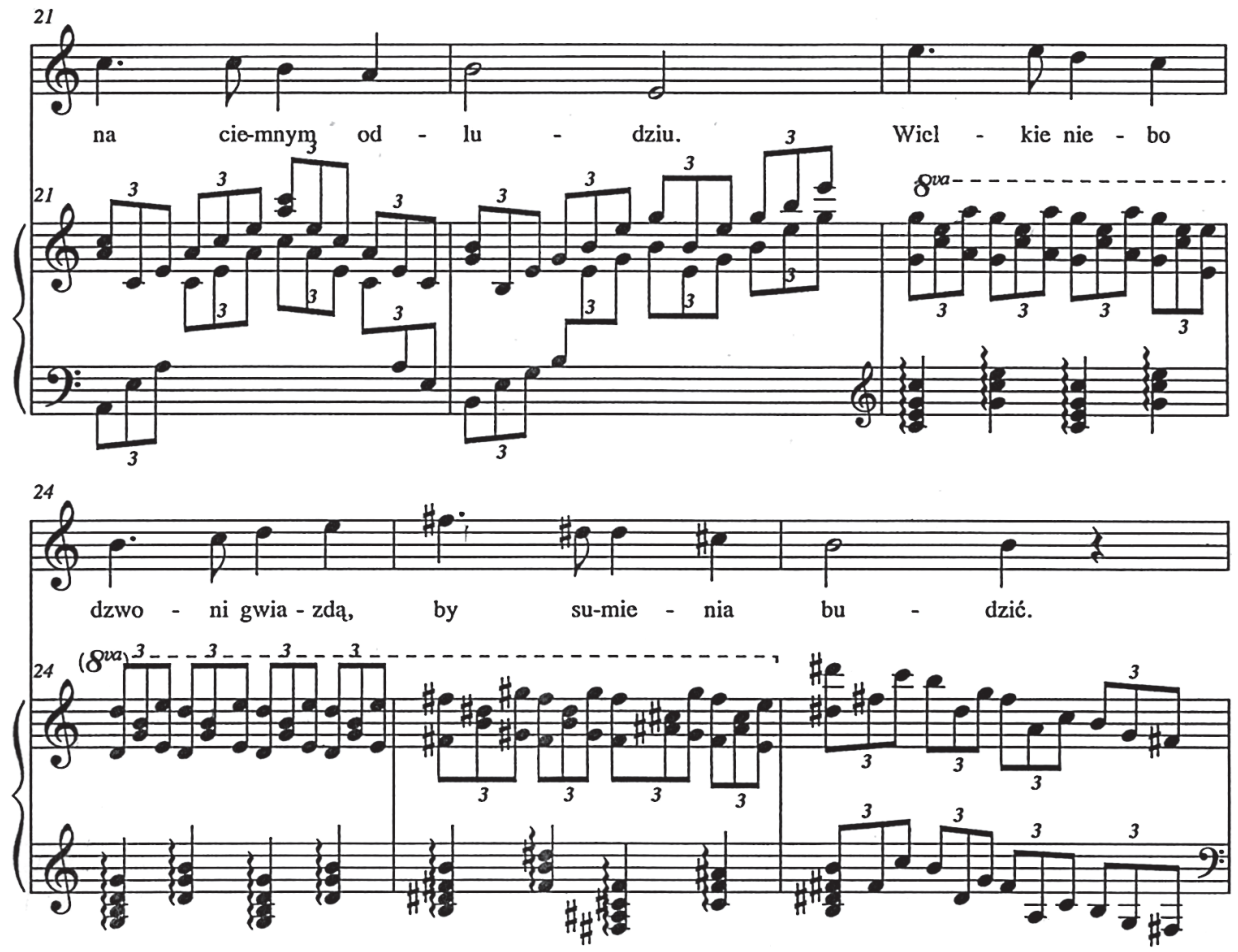
zbudzić" następuje wyższy rejestr w obu partiach (w fortepianie pojawia się przenośnik oktawowy) oraz wprowadzająca niepokój chromatyka w końcowych taktach frazy. Melodia opada, pochód ten kontynuuje fortepian, po czym następuje takt przerwy odliczony akordem powtórzonym ćwierćnutami, co stanowi wprowadzenie do $\mathrm{A}^{2}$.

Dalsze części budują napięcie w analogiczny sposób. Pod względem wokalnym utwór z całą pewnością wymaga prowadzenia legato, na co wskazuje sama forma, przypominająca pieśń. Towarzyszący soliście akompaniament zaznacza punkty kulminacyjne i odpowiadającą rozbudowującej się fakturze dynamikę (fragmenty w niższej tessiturze z ósemkowo rozłożonymi akordami mogą sugerować spokojne prowadzenie głosu, natomiast słupy akordowe - głośniejsze i bardziej dramatyczne). Na szczególną uwagę zasługuje finał kolędy, który stanowią ostatnie cztery takty do słów: „Nad stajenką światła obłok. Spada z serca kamień”. To właśnie na słowo „spada” solista osiąga najwyższy dźwięk $\left(\mathrm{g}^{2}\right)$, a twardo powtórzony akord (bohatersko rozwiązany E-dur) podkreśla ostatnie słowo - „kamień”.

\subsection{W DREWNIE}

Z pewnością drugi utwór cyklu możemy sklasyfikować jako pastorałkę. $W$ drewnie ukazuje historię ubogiego rzeźbiarza, strugającego wizerunek bożonarodzeniowej szopki. Teraźniejszość miesza się z historią betlejemską, lampa naftowa przypomina gwiazdę, a pracująca postać - świętego Józefa, stolarza. Jest to typowy dla pastorałek zabieg przenoszenia czasów narodzin Bożego Dzieciątka czy trudów Świętej Rodziny do własnego życia (Tarnowski, 1894, s. 9-11).

Jako incipit (słowny i muzyczny) pojawia się trzykrotnie „Wśród nocnej ciszy (...)”. Widać tu celowe nawiązanie do kolędy powstałej na przełomie XVIII i XIX wieku, która w 1853 roku została opublikowana w śpiewniku ks. Michała Marcina Mioduszewskiego (Bartmiński, 2002, s. 24). Śpiew ten wpisał się w tradycję współczesną, a także był wielokrotnie źródłem inspiracji. Na melodię Wśród nocnej ciszy śpiewano również pieśni patriotyczne (Szymanderska, Szymanderski, 1989, s. 56).

W tym utworze następują celowe zmiany tonacji. Pierwszy fragment rozpoczyna długi wstęp oparty na akordach kwintowo-kwartowych i skali góralskiej. Po dwunastu taktach wyłania się motyw kolędy Wśród nocnej ciszy w tonacji G-dur, po nim następuje osiem taktów w znacznie wyższej tessiturze solisty w tonacji C-dur. W ostatnim takcie frazy harmonika poprzez akord E-dur przechodzi do tonacji A-dur i kolejny raz wkracza incipit, tym razem o sekundę wyżej. Po szesnastu taktach ostatnie słowa „w legendy bramę wchodzi jak pątnik” kończą się w fis-moll. Następuje 
Przykład 2. W drewnie. Takty 8-21 (Hadyna, 2009)
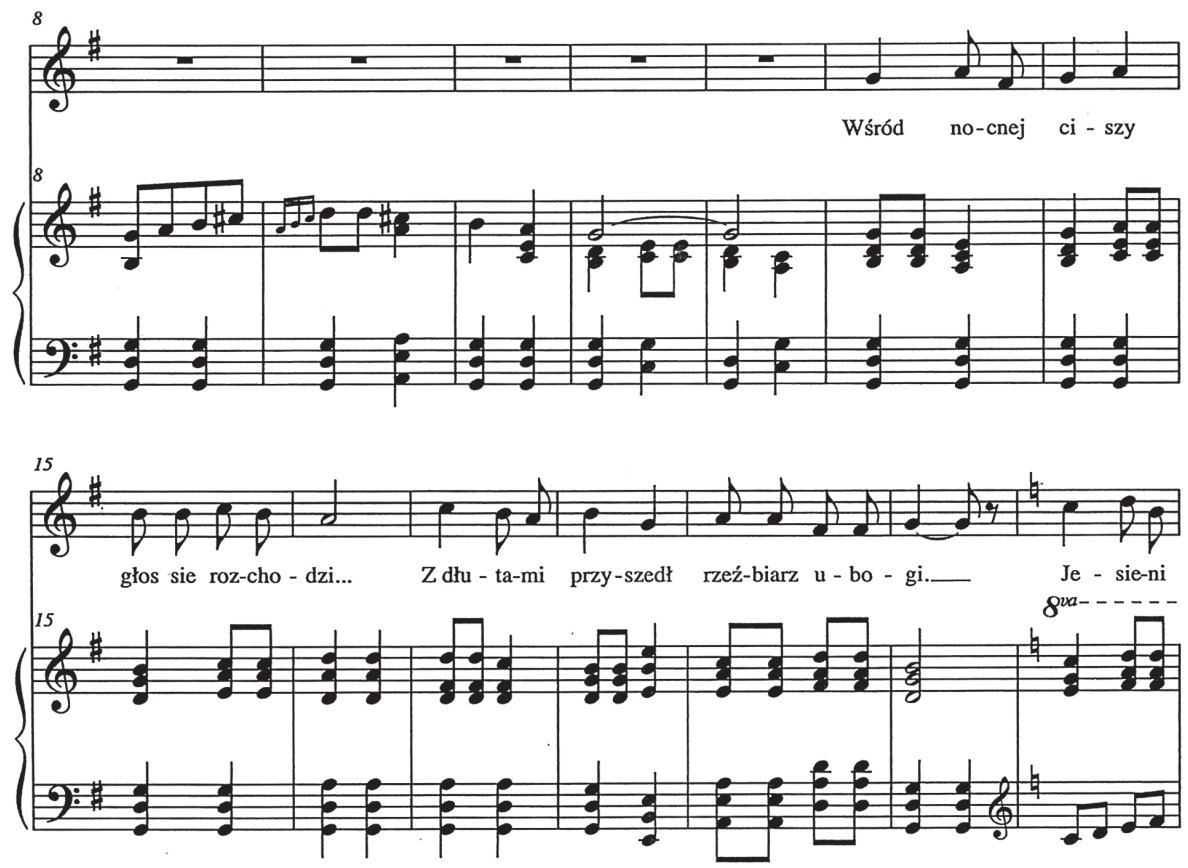

pochód akordów z wtrąceniami, a partia solisty pnie się do oktawy (od as ${ }^{1}$ do $a^{2}$ ) elementami chromatyki z dozą niepokoju do słów „Nagłą ucieczkę struga skupiony, śpiewa mu wieczność, wiatr w złotej słomie”. Bez wątpienia jest to kulminacyjny punkt utworu, zarówno zważywszy na warstwę muzyczną (kierującą się do góry - do tego, co niebiańskie i ponadczasowe), jak też tekstową (która mówi o wieczności przenikającej pracę doczesną). Dalsze słowa „Przed jego osłem i wołem z drewna jak pasterz prosty kornie przyklękam” sprowadzają do nizin ziemskich, za tym też głos prowadzony jest opadająco. Ostatnie zawołanie „Wśród nocnej ciszy” opatrzone jest meno mosso i wprowadza pointę. Na tych słowach pojawia się również ritenuto, podkreślające „Wśród nocnej ciszy dokument prawy w stodółce skryty przez tłumem marnym”. Taka wersja została wydana i jest wykonywana przez zespół Śląsk. Warto jednak wspomnieć, iż na płycie z 1986 roku Wiesław Ochman śpiewa w tym miejscu inną pointę „Faryzeuszy oczom odjęty rzeźbi staruszek drewno - jak święty”.

W drewnie jest utworem o charakterze pieśni, wymaga od śpiewaka opowiedzenia historii, przekazania treści ze zmianami charakteru (np. takty 37-58 potrzebują 
bardzo lirycznego prowadzenia frazy). Trudność może też sprawiać osiągniecie górnej granicy ambitusu (as²) poprzez wznoszącą się na przestrzeni ośmiu taktów fakturę i ritenuto. Spośród całego cyklu utwór ten wyróżniają 12-taktowe motywy góralskie (rozpoczynający i wieńczący), nienawiązujące bezpośrednio do wokalnej partii. Zapowiadają one jednak charakter utworu i kierunek interpretacji.

\subsection{POPRZEZ JEDLINĘ}

Kolejna pastorałka wraca do nastroju sentymentalnego (tempo moderato, metrum 3/4). Tekst opowiada o wspomnieniach z Karpętnej (miejsce urodzin Stanisława Hadyny), które zawsze wywoływały u kompozytora wzruszenie (Niedoba, 2010, s. 63-73). Co więcej, autor świadomie łączył rodzinną wieś z miejscem w pewnym sensie „biblijnym”. Wracając pamięcią do zbieranych przez ojca ludowych piosenek i melodii tańców, nie mógł uniknąć związku z miejscem ich pochodzenia (Niedoba, 2010, s. 73). Nawiązywanie w utworach świątecznych do lat dziecięcych, ciepła domowego i rodzinnych stron to stałe tematy, występujące od początku w tego typu pieśniach (Tarnowski, 1894, s. 8-12). Spokojny charakter utworu, powtarzane na jednej wysokości nuty oraz łagodnie prowadzona melodia wspierają przekazanie treści.

Budowę muzyczną partii wokalnej pastorałki można przedstawić za pomocą następującego schematu (gdzie każdej kolejnej części przypisany jest inny fragment tekstu): A A B ${ }^{1} \mathrm{~B}^{2} \mathrm{~A} \mathrm{~A} \mathrm{~B}{ }^{1} \mathrm{~B}^{3}$. Utwór posiada zatem zaplanowaną strukturę zwrotkową, a części określone jako B tworzą pewien refren lub różne wykończenie danego fragmentu. Różnią się one zaledwie kilkoma dźwiękami. Ambitus głosu mieści się w granicach $\mathrm{e}^{1}$ - fis ${ }^{2}$ i większość partii umieszczona została w wygodnym zakresie.

Na zwrócenie uwagi zasługuje końcowy fragment pastorałki do słów „W noc wigilijną świat zagrożony odwiedza Bóg niestrudzony”, gdzie na ostatnich słowach solista poprzez pasaż akordu H-dur osiąga f² i kończy frazę na długo trzymanym e². Chociaż nie są to granice skali głosu wysokiego, to konstrukcja i charakter utworu sprawiają, że na tych słowach pojawia się bardzo wyraźna pointa.

\subsection{NIEŚLI GWIAZDĘ Z DREWNA}

Pastorałkę Nieśli gwiazdę z drewna rozpoczyna pochód w skali góralskiej (od d) oraz pulsujące w ćwierćnutach kwarty i kwinty w prawej ręce fortepianu w metrum 2/4. Te 4 takty wstępu wprowadzą żywy, góralski. Partia wokalna wyróżnia się niezwykłą prostotą melodii, która w prawie całym utworze nie zawiera innych 
Przykład 3. Nieśli gwiazdę z drewna. Takty 42-55 (Hadyna, 2009)
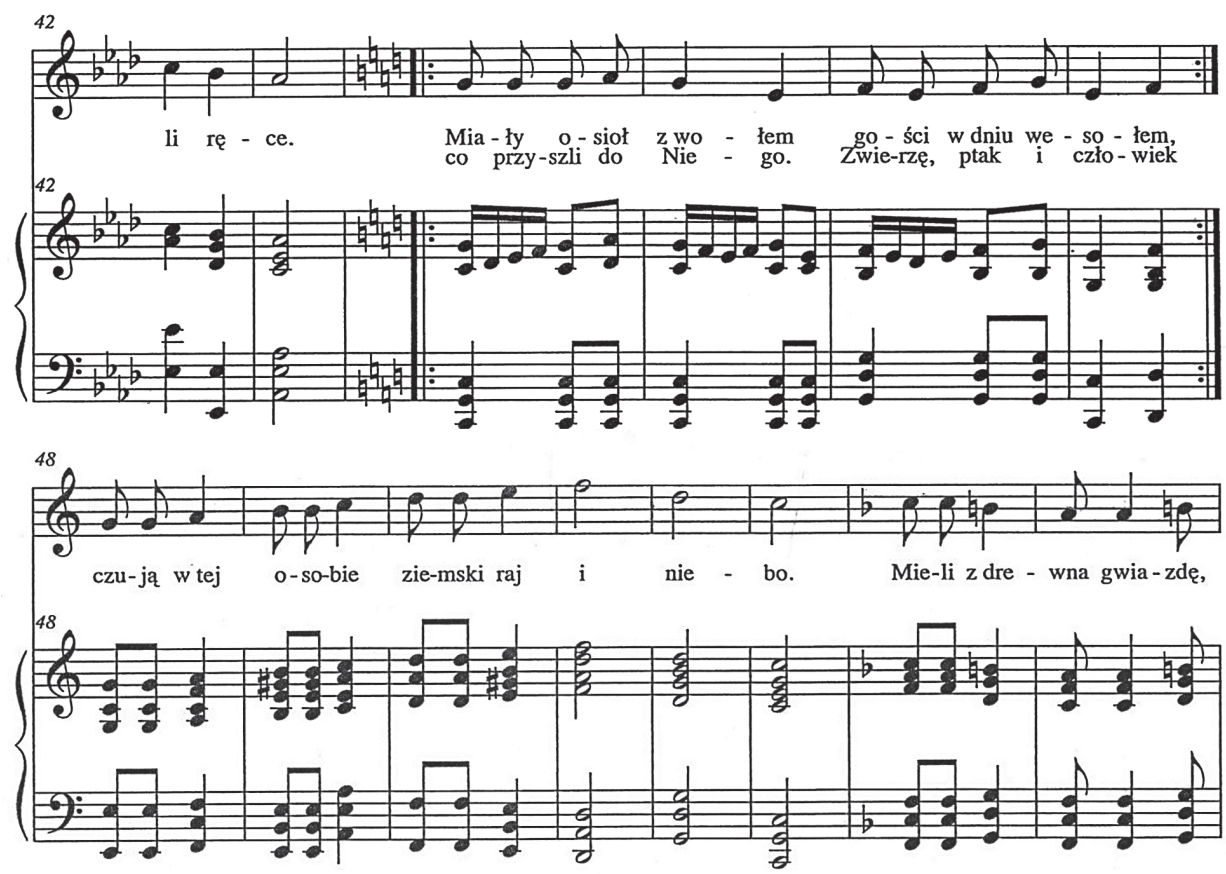

interwałów niż sekundy. Przypomina to naturalny, ludowy śpiew, wzbogacony energiczną rytmiką. Podobnie jak w wielu pastorałkach cyklu, Hadyna podnosi tonację i tessiturę solisty w poszczególnych zwrotach: dwanaście taktów od słów „Nieśli gwiazdę z drewna” opiera się na D-dur, kolejna analogiczna objętościowo część rozpoczyna się w F-dur i dalej w As-dur. Dalsza fraza zawiera w sobie wznoszenie dźwięków wraz z tekstem mówiącym o tym, co niebiańskie. Ponadto na słowa „i niebo” zostają wprowadzone długie wartości rytmiczne (półnuty) zarówno w wokalu (najwyższy do tej pory dźwięk utworu - $\mathrm{f}^{1}$ ), jak i akompaniamencie.

Jest to samoczynne „zwolnienie” i podkreślenie istotnego momentu, po którym powraca skoczny charakter. Po dwunastu taktach melodia wspina się w analogiczny sposób (do g²), po czym wydzielone zostaje „przyklęknął”. Akompaniament wybrzmiewa razem z solistą trzymającym $\mathrm{f}^{2}$. W tych czterech końcowych taktach na nagraniu realizowane jest również ritenuto oraz fermata przed ostatnim słowem. Tekst pastorałki nawiązuje do podróży pasterzy, juhasów i Trzech Króli do stajenki, jak również do współczesnego zwyczaju kolędowania z gwiazdą. Ponownie miesza się historia biblijna z teraźniejszością, a pointą jest wspólne oddanie pokłonu 
Dzieciątku i Panience. Hadyna w interesujący sposób zinterpretował treść, umieszczając skoczny, góralski wstęp na początku i zostawiając ciszę po wybrzmieniu słowa „przyklęknął”.

\subsection{LUDZKIM GŁOSEM}

Ludzkim głosem to bardzo spokojna pastorałka (lento) o budowie $\mathrm{A}^{1} \mathrm{~A}^{2} \mathrm{~A}^{2}$. Śmiało można powiedzieć o trzech zwrotkach utrzymanych w jednym, kołysankowym charakterze. Widoczne są w niej również inspiracje zaczerpnięte z sentymentalizmu Marii Szymanowskiej (Bauman-Szulakowska, 2000, s. 21). Harmoniczna całość, poza małymi odchyleniami w stylu muzyki współczesnej, opiera się na tonacji g-moll. W finalnym akordzie mollowym następuje doprowadzenie do seksty wielkiej, co podkreśla magiczny nastrój całego utworu, opowiadającego o zwierzętach przemawiających ludzkim głosem podczas nocy wigilijnej.

Partia wokalna zazwyczaj przebiega w wygodnej średnicy (ambitus $\mathrm{d}^{1}-\mathrm{f}^{2}$ ), a większość melodii jest dublowana w akompaniamencie (jak również w partii orkiestrowej). Elementem wyróżniającym się na tle cyklu jest staccato wprowadzone na ostatnich nutach drugiej i trzeciej zwrotki, zarówno w orkiestrze, jak i partii wokalnej.

\subsection{OPŁATEK DLA MAMY}

Opłatek dla mamy to utwór niezwykle wzruszający, nawiązujący do wspomnień obudzonych przez symbol białego opłatka. Składa się z trzech zwrotek i cody która jest prawie dokładnym powtórzeniem pierwszych ośmiu taktów. Dwie pierwsze części zachowują taką samą strukturę melodyczną, natomiast trzecia umiejscowiona jest w wyższym rejestrze. Pastorałka rozpoczyna się w g-moll, jednak szczególnie w ostatniej zwrotce znajduje się wiele zmian harmonicznych. W codzie powraca początkowy motyw, tym razem jednak rozwiązany do finalnego B-dur.

Wersja orkiestrowa zaczyna się od 16-taktowego wstępu, w którym istotną rolę odgrywa partia wiolonczeli, również w całej kompozycji pełniąca funkcję koncertującą. W wyciągu fortepianowym wprowadzenie zostało skrócone do pięciu taktów. Utwór utrzymuje się w kołyszącym metrum $\%$, w charakterze cantabile. Jest to pierwsza pastorałka z cyklu, w której z racji podkreślenia akcentów słownych wiele fraz wokalnych zaczyna się od przedtaktu. Na przykładzie tego utworu widać wyjątkową dbałość Hadyny o wykorzystanie naturalnej śpiewności języka, kiedy to akcent wyrazowy pokrywa się z melodycznym i rytmicznym. 
Przykład 4. Opłatek dla mamy. Takty 49-53 (Hadyna, 2009)

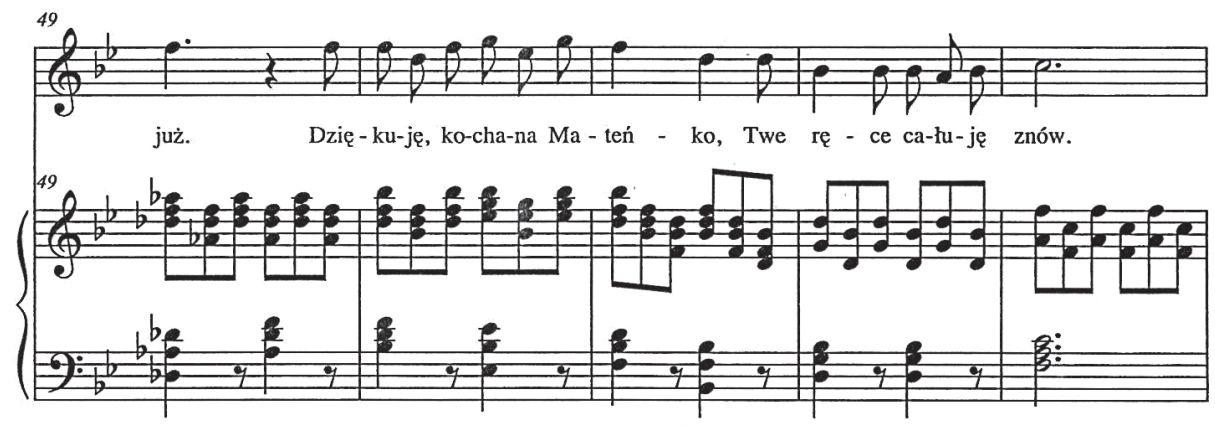

Moment przełamujący stabilność następuje w takcie 40. na słowach „o Zbawcy, co zbawił nasz świat”. W wykonaniu płytowym w tym miejscu zastosowano duże ritenuto na wyjątkowym piano, co z racji skoku o sekstę w górę wymaga niemałej kondycji wokalnej. Dalsza część również przebiega w wolniejszym tempie (czego jednak nie sugeruje edycja nutowa). Napięcie narasta wraz z tessiturq̨ do trudnej wokalnie kulminacji na słowach „Dziękuję, kochana Mateńko”, gdzie przez dwa takty solista utrzymuje się wyłącznie w najwyższym rejestrze skali i rozładowuje napięcie w opadającym pochodzie przy słowach „Twe ręce całuję znów”.

Cały utwór jest niezwykle poruszający, a melodyka i harmonia przypomina trochę kołysanki, które odwiecznie wiążą się z obrazem matczynego ciepła. Jest to pastorałka szczególnie istotna również dla samego kompozytora, który ze wzruszeniem wracał do niej wielokrotnie w swoich notatkach i wspomnieniach.

\subsection{POLONEZ KOLĘDA}

Już tytuł sugeruje źródło inspiracji kolejnego utworu cyklu. Polonez kolęda, zgodnie z zapowiedzią, jest utrzymana $\mathrm{w}$ metrum $3 / 4 \mathrm{w}$ tempie moderato, a cha-

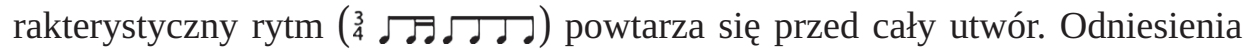
patriotyczne (a nawet wojenne) nie są nowością w kolędach i pastorałkach. Często wykorzystywano znane świąteczne melodie, przypisując im powstańcze lub wygnańcze teksty (Skoczek, Załęczny, Gmitruk, 2017, s. 17-18). W utworze Polonez kolęda pojawiają się bezpośrednie nawiązania do poloneza (Marchwica, 1996) - jako melodii tańca oraz do Mazurka Dąbrowskiego, zarówno w tekście jak i we fragmencie melodii.

Również tutaj zostaje zaintonowany Mazurek Dq̨browskiego, do którego Hadyna miał ogromny sentyment. Na temat powstania tej pieśni napisał książkę pt. 
Przykład 5. Polonez kolęda. Takty 40-49 (Hadyna, 2009)
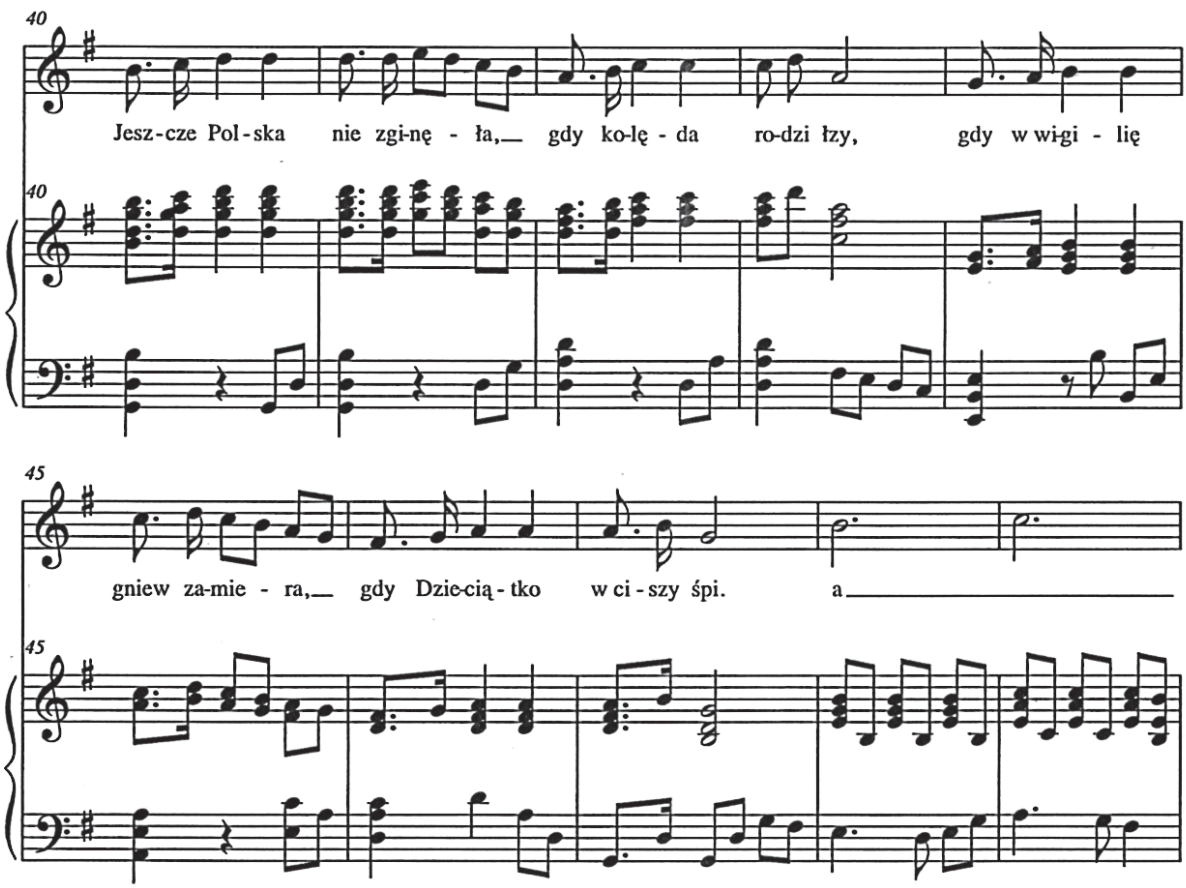

Droga do hymnu, w której została przedstawiona próba wniknięcia w specyfikę utworu na tle historycznym, z uwzględnieniem etapów tworzenia (Hadyna, 1989).

Powyższy fragment pokazuje także kolejny wyjątkowy zabieg - wprowadzenie wokalizy. Może być ona intepretowana jako motyw kołysankowy, służący do utulenia Dzieciątka (o którym przed chwilą śpiewał solista), jak też zawołanie pełne łez (które „rodzi kolęda”).

W dalszej części zostaje zacytowana najbardziej znana polska kolęda oparta na polonezie - Bóg się rodzi. Dopełnia to wykorzystanie wątków narodowych i patriotycznych. Przeplatanie melodyczne i autorskie rozwiązywanie intonowanych motywów przebiega bardzo płynnie, co świadczy o wyjątkowym kunszcie kompozytora.

Budowę kolędy można określić jako A ${ }^{1}$ B C A², kiedy w ostatniej części następuje rallentando i poprowadzenie do bohaterskiego $\mathrm{g}^{2}$, trwającego trzy końcowe takty. Instrumentalne zakończenie wzorowane jest na typowej kadencji występującej w polonezie. Cały utwór przepełnia podniosły i wdzięczny nastrój, odpowiadający treści i wszystkim wskazanym inspiracjom. 
Przykład 6. Polonez kolęda. Takty 40-55 (Hadyna, 2009)

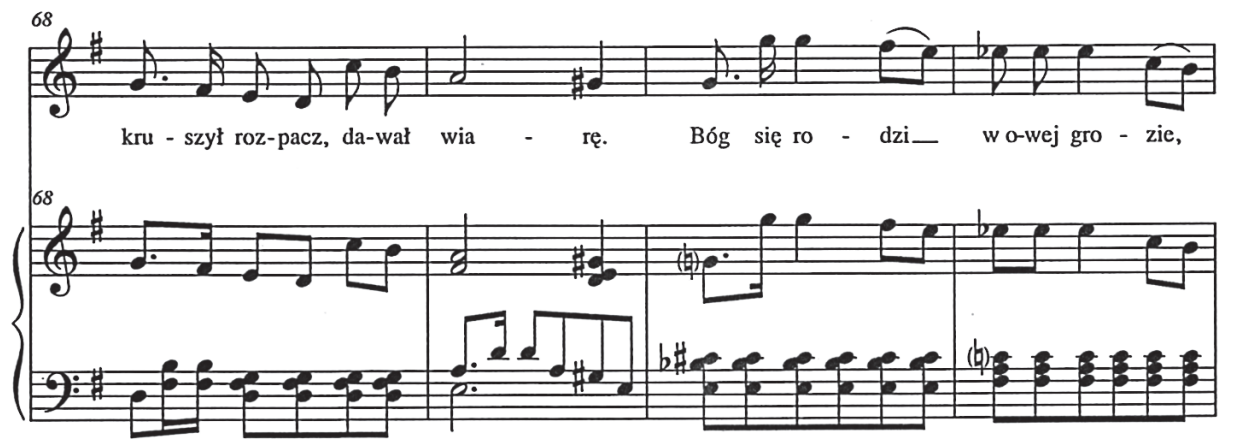

\subsection{PASTERZE NIE ZWLEKALI}

Po podniosłym patriotycznym akcencie pojawia się skoczna, wręcz prosta w formie kolęda Pasterze nie zwlekali. Tempo allegretto, metrum $2 / 4$ oraz oparty na interwałach kwinty akompaniament podkreślają lekki charakter i swoistą prostotę pasterzy biegnących do stajenki. Budowa utworu zamyka się w formie AABBCC, którym odpowiednio przypisane są tonacje: G-dur, C-dur, A-dur. Ze strony wokalnej można traktować ten utwór jako pewien odpoczynek (w połowie cyklu), po dużo bardziej wymagającej technicznie Polonez kolędzie. Ambitus mieści się od $\mathrm{d}^{1}$ do $\mathrm{g}^{2}$, jednak tessitura utrzymuje się głównie w wygodnej średnicy głosu wysokiego. Utwór ma prosty, dwutaktowy wstęp i zakończenie równe z ostatnim dźwiękiem partii solisty.

Najprawdopodobniej melodia zainspirowana była góralską przyśpiewką, co zgodne jest z charakterem, budową, formą i treścią całej kolędy. Metrum, melodyka i rytmika oddają radosny nastrój pasterzy oraz ich pośpiech w dążeniu do stajenki. Utwór wymaga również odpowiedniego wykonania wokalnego, by przy zachowaniu lekkości i prostoty nie zagubić dobrego warsztatu.

\subsection{KANY W ZBOŻU}

Kany w zbożu to jedyna część cyklu w całości napisana gwarą. Jest to prośba o udzielenie błogosławieństwa w sprawach codziennych pobożnym góralom. Pastorałka została napisana w metrum 2/4 w tempie allegretto, a harmonicznie dominuje w niej skala góralska w różnych rejestrach, pochody całotonowe oraz piony akordowe oparte na interwałach kwintowo-kwartowych. Utwór zbudowany 
został na schemacie A A ${ }^{1} \mathrm{~B} \mathrm{~B}^{1} \mathrm{C} \mathrm{C}^{1} \mathrm{D} \mathrm{D}^{1} \mathrm{C} \mathrm{C}^{1} \mathrm{z}$ 4-taktową codq. Z każdą częścią podnoszona jest tessitura solisty, natomiast we fragmencie $\mathrm{D}$ następuje zmiana charakteru, harmonii i faktury akompaniamentu (w stronę sentymentalizmu). Chociaż wersja nutowa z wyciągiem nie zawiera żadnych uwag odnośnie do dynamiki czy artykulacji, sugerując się nagraniem płytowym i zmianami w orkiestrze, można temu fragmentowi przypisać ritenuto i piano mistico. Jest to jedyny moment, który w warstwie tekstowej odbiega od spraw przyziemnych, a mówi o zbawieniu czekającym na górali w stajence. Jak w całym cyklu, także i tym razem Stanisław Hadyna świadomie wyróżnia sferę sacrum i profanum, wykorzystując bogactwo harmoniczne i kompozytorski kunszt. Po tym krótkim fragmencie uniesienia żwawo wraca motyw z części C i doprowadza do bohaterskiego, góralskiego zawołania „z weselem, hej!” utrzymanego na $\mathrm{a}^{2}$. Stanowi to bardzo energiczne i oryginalne na przestrzeni cyklu zakończenie.

\subsection{SKRZYP, SKRZYP}

Skrzyp, skrzyp to czterozwrotkowy utwór, opisujący codzienność różnych postaci w świątecznym czasie. Wszystkie sytuacje zespalają onomatopeiczne „skrzyp, skrzyp” oraz parlandowane powtórzenia „idą kolędnicy”.

Utwór utrzymany jest w tempie allegretto w metrum $2 / 4$, a na tle cyklu wyróżnia się warstwą instrumentalną, w której poniekąd przebiega dialog z solistą. Po każdej krótkiej frazie w partii wokalnej następuje dwu- lub trzytaktowa przerwa, uzupełniona niczym echo akompaniamentem. Po raz pierwszy w ramach cyklu kompozytor wykorzystuje jako środek wyrazu parlando-półszept, wprowadzając nastrój tajemnicy i oczekiwania kolędników, co w kontekście tekstu każdej

Przykład 7. Skrzyp, skrzyp. Takty 27-33 (Hadyna, 2009)

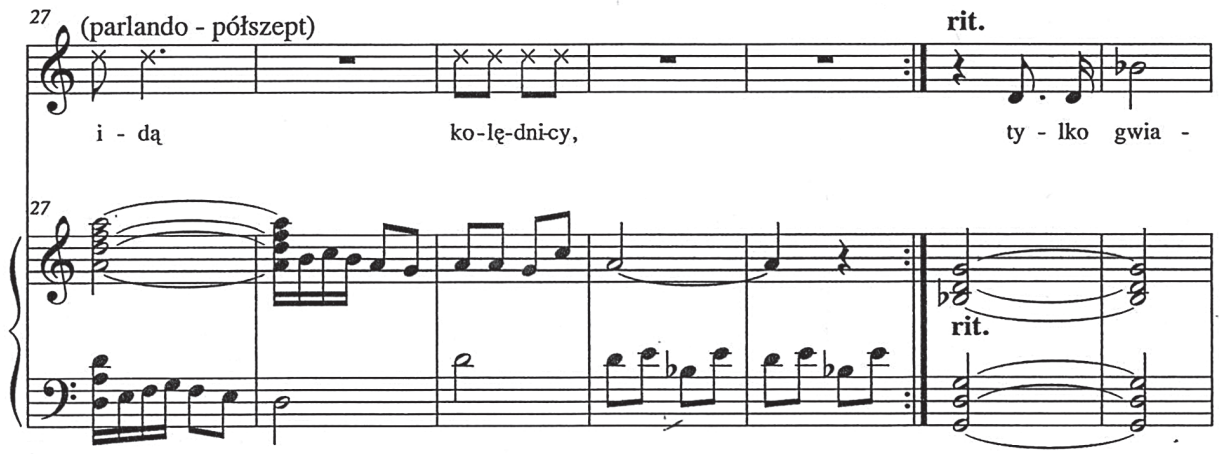


ze zwrotek może być intepretowane w inny sposób. Ostatni fragment ukazuje staruszkę, którą odwiedza „samotna gwiazda”. To podsumowanie wymaga od śpiewaka niezwykłej ekspresji i dobrego przygotowania wokalnego. Przy pierwszej części zakończenia po skoku oktawy solista utrzymuje g², natomiast po dopowiedzeniach orkiestry i powrocie do tempa również w dynamice piano kończy utwór, trzymając $\mathrm{a}^{2}$. Jest to zaskakujące i piękne zakończenie, którego nie zapowiada cały lekki i zwrotkowy utwór.

\subsection{NA PASTERKĘ GÓROLE}

Po łagodnym i wzruszającym Skrzyp, skrzyp następuje żwawe, energiczne i pełne podhalańskich inspiracji Na pasterkę Górole. Podobnie jak w Nieśli gwiazdę z drewna znaczącą rolę odgrywa tutaj rytmika, w tym punktowane i synkopowane wartości. Pastorałka napisana została w tempie moderato i metrum 2/4, podkreślonym przez interwały kwintowe (realizowane w basie). Na tle całego cyklu utwór ten wyróżnia fanfarowy, uroczysty charakter. Akordowe piony sugerują, aby naśladujące zawołanie - „Górole, Górole, na Pasterkę, hej!” - wykonywać donośnym głosem.

Fanfarowe motywy pojawiają się jako dopowiedzenie orkiestrowe w taktach 53 i 69. Budują podniosły nastrój i podkreślają wielokrotnie powtarzające się zawołanie „hej”. Ten utwór jest z pewnością wymagający pod względem wokalnym. Nieprzewidywalne zmiany harmoniczne, liczna chromatyka, wysoka tessitura oraz trudności artykulacyjne związane z ekspresją i wymową tekstu w skocznym tempie wymagają odpowiedniego przygotowania. Szczególnie wspinająca się melodia w ostatnich taktach i końcowe, podsumowujące „hej” ( $\left.\mathrm{a}^{2}\right)$ musi zabrzmieć wyjątkowo donośnie.

Przykład 8. Na pasterkę Górole. Takty 22-28 (Hadyna, 2009)

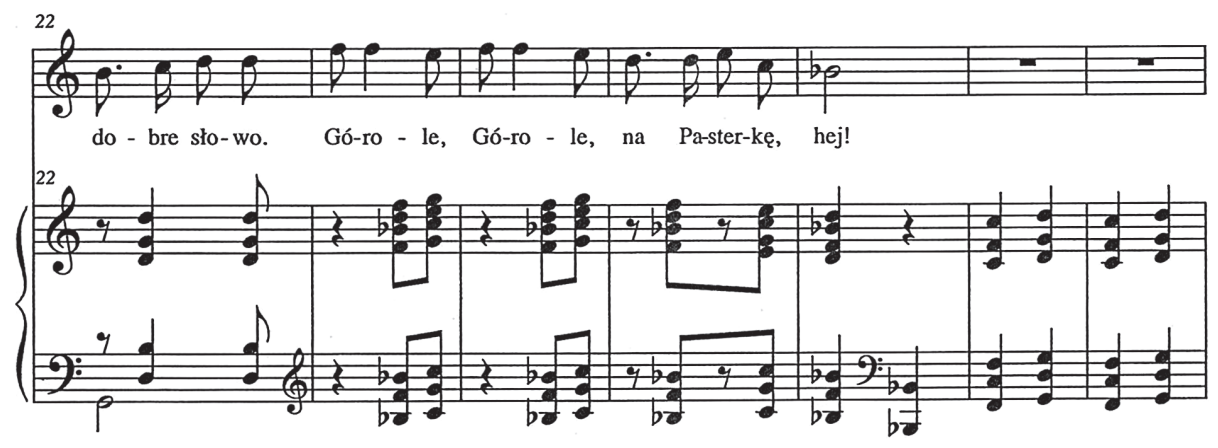




\subsection{KOLĘDA O TYM, CO BYŁO}

Kolęda o tym, co było wspomina dawne czasy, zarówno rzeczywistego Bożego Narodzenia, jak sposobu świętowania z młodzieńczych lat. Utwór składa się z dwóch równych zwrotek. Rozpoczyna się w metrum 3/4, po czym od taktu 17. zmienia się sposób prozodii i metrum na $6 \%$. Z pewnością ta pastorałka wyróżnia się także rozbudowanymi, chromatyzowanymi pasażami w akompaniamencie, które wybrzmiewają podczas kończących frazę długich nut solisty.

Melodia napisana została w wygodnej tessiturze i w większości znajduje się w średnicy głosu wysokiego (ambitus $\mathrm{g}^{1}-\mathrm{g}^{2}$ ). Fraza układa się dwutaktowo, z pokrywaniem się akcentów muzycznych i językowych. By lepiej oddać naturalną prozodię tekstu, kompozytor wykorzystuje przedtakty w metrum $6 / 8$ oraz wydłużanie nut na opartych intonacyjnie sylabach. Dzięki temu utwór nie stawia zbyt wielu trudności technicznych w partii wokalnej, a wręcz sprzyja właściwej interpretacji. Zaskakująca może być jedynie harmonika, którą obficie wypełniają modalizmy i nieutwierdzone żadną tonacją następstwa akordów. O ile początkowy

Przykład 9. Kolęda o tym, co było. Takty 7-13 (Hadyna, 2009)

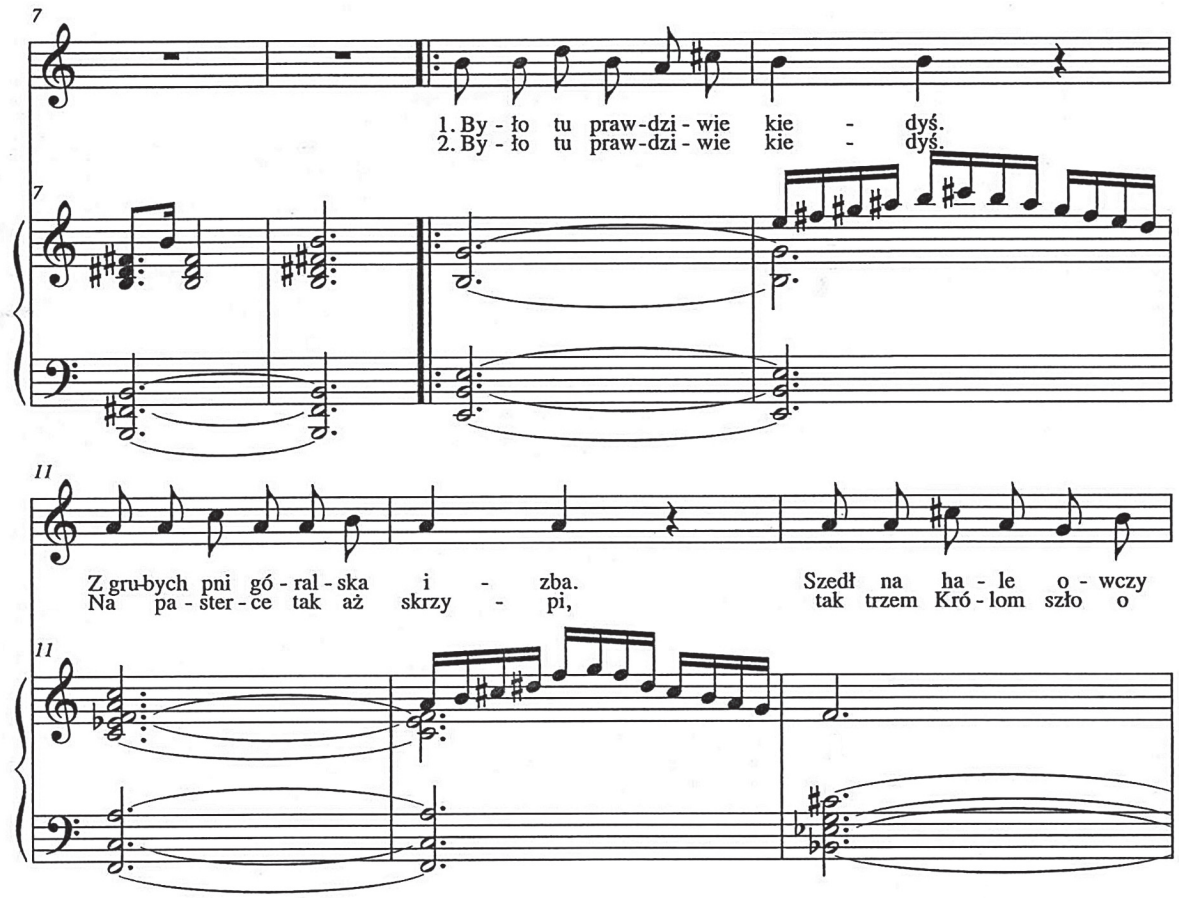


fragment mógłby opierać się na skali ludowej, to w momencie zmiany metrum na $6 / 8$ trudno doszukać się bazowej tonacji. Kolejne takty zahaczają o g-moll, F-dur, B-dur czy c-moll, przy czym melodia solisty rozwiązuje się w D-dur. Utwór kończą całotaktowe piony akordowe w następstwach D-dur, H-dur, F-dur, H-dur. Te charakterystyczne w twórczości Stanisława Hadyny zabiegi wskazują na łączenie tradycyjnych i nowoczesnych form kompozycyjnych.

\subsection{3. ŚWIĘTA TO BIELE}

Święta to biele to pastorałka utrzymana w bardzo radosnym i skocznym nastroju (allegretto grazioso). Szczególnie szybkie ósemkowe pasaże w akompaniamencie zdradzają inspirację zaczerpniętą z polskich tańców narodowych. Tezę tę potwierdza 16-taktowy fragment instrumentalny kończący każdą część utworu.

Kompozycja ma budowę zwrotkową, gdzie trzy strofy tekstu przypisane są do powtarzającej się melodii, natomiast ostatnia, czwarta, jak w wielu poprzednich

Przykład 10. Święta to biele. Takty 35-46 (Hadyna, 2009)
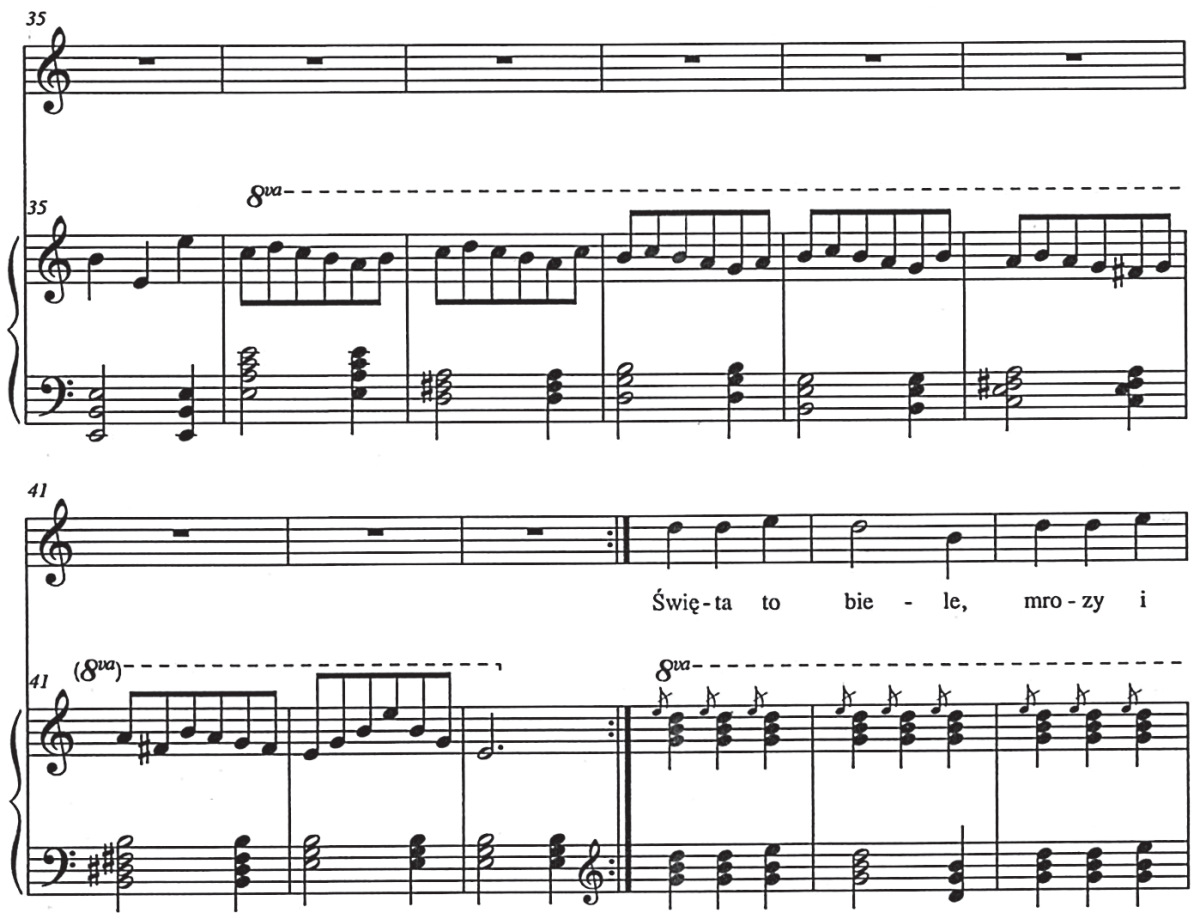
utworach, rozpoczyna się o tercję wyżej. Większość ostatniego fragmentu oscyluje w dość wysokiej tessiturze (pomiędzy d²-g²). Ponadto w końcówce solista osiąga i powtarza najwyższy dźwięk z całego cyklu - $\mathrm{h}^{2}$.

\subsection{GDY OKIENKA CHAT JUŻ PŁONA}

Pastorałka wieńcząca cykl to liryczne zamyślenie nad tradycyjną polską wigilią. Utwór składa się z dwóch jednakowych zwrotek utrzymanych w moderato, metrum $4 / 4$. Pulsujące $\mathrm{w}$ akompaniamencie szesnastki zmuszają do prowadzenia przez solistę frazy z wyjątkowym legato. Przez sentymentalny charakter i spokojną rytmizację kompozytor łagodną refleksją zamyka całą formę.

Melodia solisty delikatnie wspina się przez cały utwór, bazując w wyższej tessiturze w kolejnych fragmentach. Doprowadzona zostaje do prawie najwyższych dźwięków całego cyklu (as² i b²), po czym wybrzmiewa ostatnią nutą - $\mathrm{g}^{2}$. Finał utworu różni się nieco w wersji nagraniowej, w wykonaniu Wiesława Ochmana.

Przykład 11. Gdy okienka chat już płoną. Takty 23-26 (Hadyna, 2009)
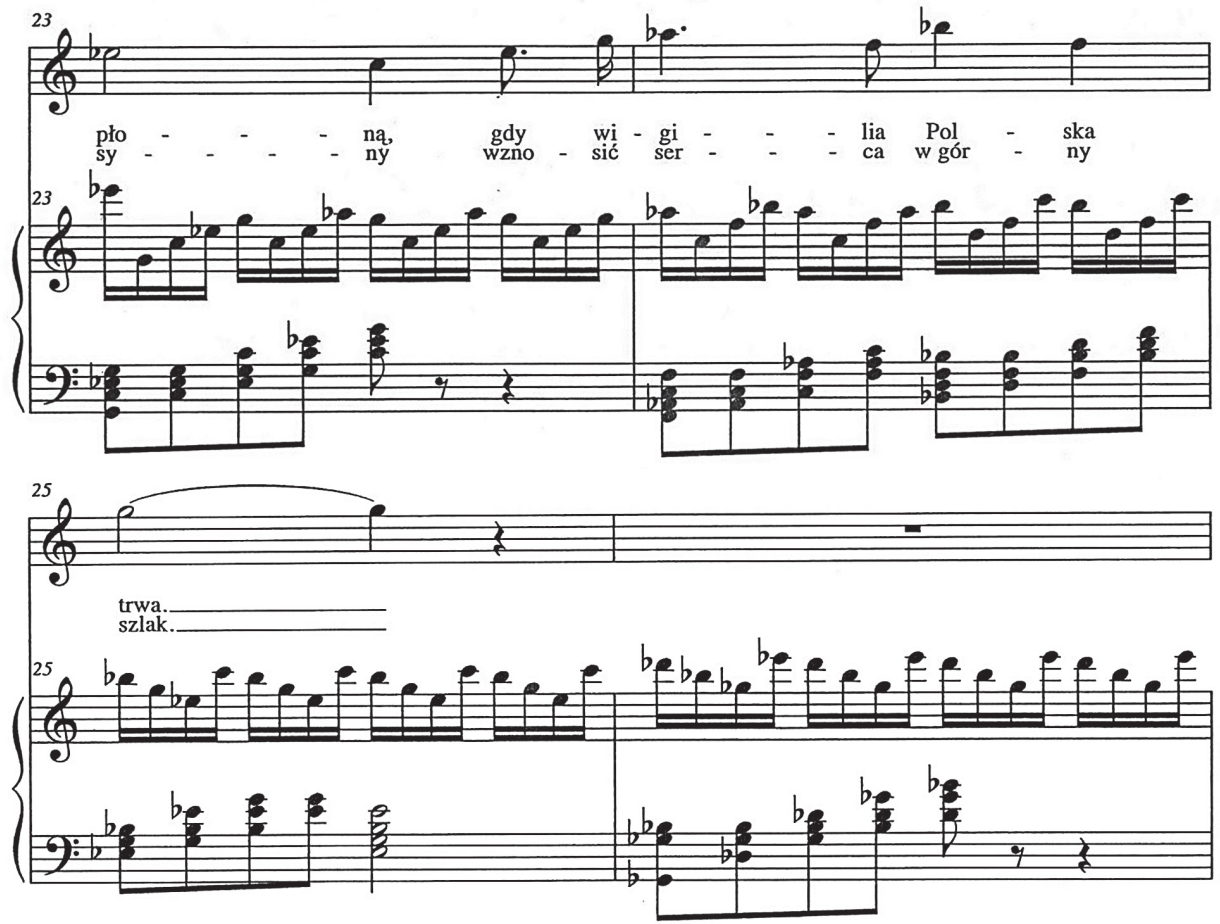
Solista w przedostatnim takcie nie zaczepia $\mathrm{as}^{2} \mathrm{i} \mathrm{b}^{2}$, lecz czterokrotnie, $\mathrm{z}$ niezwykłym spokojem powtarza dźwięk $\mathrm{f}^{2}$ i z tego wchodzi na końcowe $\mathrm{g}^{2}$. Być może to rozwiązanie jest korzystniejsze w perspektywie wykonywania całego cyklu, gdyż wiele wcześniejszych jego momentów wymagało mierzenia się z trudnymi zadaniami wokalnymi.

Istnieją znaczące różnice tego utworu, pomiędzy jego pierwotną wersją, która została zarejestrowana w roku 1985 (Ochman, 1985), a wydana w 2009 przez Officina Silesia (Hadyna, 2009). Słowa na nagraniu opowiadają o wspólnym, rodzinnym śpiewaniu kolęd i mocy polskiej wigilii. Tą przywołaną zwrotką o konieczności wspólnego kolędowania (budzącego poczucie realnego uczestnictwa w pewnym misterium) autorzy kończą cykl, dopełniając świątecznej tradycji.

\section{CAŁOŚCIOWE SPOJRZENIE NA CYKL}

Każda forma cykliczna zawiera w sobie planowane następstwo części pod względem melodyki, rytmiki, dynamiki faktury i innych. Istotne są również momenty kulminacyjne i zmiany charakteru oraz nastroju w obrębie całego dzieła. Powinny wystąpić także elementy integrujące różnorodną całość. Wszystkie te cechy odróżniają cykl od zbioru, w którym to wybór i kolejność utworów nie tworzą tak spójnej formy.

Analizowane kolędy i pastorałki Stanisława Hadyny posiadają znamiona charakterystyczne dla całej jego twórczości. Kompozytor wielokrotnie rozszerza system dur-moll swobodnymi zestawieniami akordów i efektami modalnymi (W drewnie, Nieśli gwiazdę z drewna, Kany w zbożu, Na pasterkę Górole). Zabiegi te łączy zazwyczaj z wykorzystaniem skali ludowej (góralskiej) i interwałów kwintowo-kwartowych oraz treścią nawiązującą do tradycji podhalańskich lub pilnujących owiec pastuszków. We wszystkich częściach obficie wykorzystana została chromatyka, zarówno w partii solisty, jak też instrumentalnej. Wiele utworów w charakterze nawiązuje do typowych kolędom kołysanek, za czym przemawia śpiewność fraz, barwa akompaniamentu (szczególnie oddana przez wersję orkiestrową) oraz tematyka (Narodziła nam się dobroć, Poprzez jedlinę, Opłatek dla mamy, Kolęda o tym, co było, Gdy okienka chat już płonq). Powyższy podział kompozycji pokazuje również naprzemienne zestawianie charakteru sentymentalnego ze skocznymi i rytmicznymi inspiracjami muzyką ludową i góralską. W cyklu kolędowym nie mogło zabraknąć także dosłownej kołysanki, która od wieków istnieje w tradycji, jako pieśń śpiewana śpiącemu Dzieciątku. Niestety poruszająca Kolęda Kołysanka została uwieczniona jedynie w wersji płytowej, 
jako numer XII, natomiast w publikacji nut w tym miejscu pojawia się Kolęda o tym, co było, której nie odnajdziemy w wykonaniu Wiesława Ochmana.

Warto wyróżnić momenty kluczowe w przebiegu kompozycji, a do takich bez wątpienia zalicza się Opłatek dla mamy. Jest to utwór wyjątkowo poruszający, zarówno pod względem treści, jak i melodyki. Sam kompozytor wielokrotnie zdradzał swoje ogromne przywiązanie do tej pastorałki. Niezwykła symbolika opłatka budzi wspomnienia lat dziecinnych, matczynych dłoni i nauki kolęd. Opłatek dla mamy jest poniekąd kulminacją sentymentalnych fragmentów - związanych $\mathrm{z}$ ciepłem domowego ogniska.

W samym środku cyklu, jako utwór VII, umiejscowiona została Kolęda Polonez. Jest to najbardziej dosłowny z akcentów patriotycznych, zarówno w treści, jak i w nawiązaniu muzycznym do poloneza, Mazurka Dąbrowskiego i Bóg się rodzi. Kompozytor otwarcie przyznaje się do korzystania ze źródeł kultury polskiej oraz tradycji innych twórców (np. nurtu narodowego Stanisława Moniuszki), co dzieje się również w innych częściach (Na pasterkę Górole, Kolęda o tym, co było, Święta to biele, Gdy okienka chat już płonq).

Pierwszy i ostatni utwór zamykają klamrę kompozycyjną tematycznie i muzycznie. Narodziła nam się dobroć zapowiada wszystkie aspekty narodzin i oczekiwania, a Gdy okienka chat już płonq opisuje nastały w wigilię domowy spokój oraz rady na lepsze życie, które można też traktować jako perspektywę wieczności. Końcowymi słowami „wznosić serca w górny szlak” solista w najwyższej tessiturze zamyka całość cyklu, a resztę dopowiada muzyka z finalnie rozbrzmiewającym B-dur. Oba te utwory utrzymane są w podobnym nastroju i rytmice oraz bazują na długiej, spokojnej, 4-taktowej frazie wokalnej.

Powyższe argumenty wskazują wybrane aspekty zaplanowania cyklu Narodziła nam się dobroć. Nie wyklucza to jednak możliwości wybiórczego wykonywania utworów według innego klucza (muzycznego lub tematycznego) bądź wykorzystania jednej kolędy czy pastorałki w odłączeniu, na co pozwala samodzielne bogactwo artystyczne każdej z nich.

\section{PODSUMOWANIE}

Stanisław Hadyna zasłynął przede wszystkim ze „Śląska”, który był dziełem jego życia, warto jednak pochylać się również nad twórczością niezwiązaną bezpośrednio z zespołem. Chociaż niewiele źródeł wspomina o cyklu kolęd i pastorałek Narodziła nam się dobroć, bliscy Profesora wiedzieli, jak wiele znaczył ten zbiór. Od początku zawierał w sobie wartość nie tylko muzyczną i kulturową, ale też 
pełne emocji i drżenia serca inspiracje włożone w opracowania. Warto przytoczyć fragment z przemówienia nad grobem śp. Stanisława Hadyny, kiedy to wymieniano największe jego zasługi:

(...) Jakby i tego było mało, siada przy fortepianie i pisze cudowne melodie do słów Kazimierza Szemiotha. Zaśpiewane przez Wiesława Ochmana kolędy trafiają do serc swym lirycznym pięknem, w którym dźwięczy i echo dawnej Karpętnej, i głos matki, i skrzypienie śniegu pod nogami tych, którzy wczesnym bożonarodzeniowym rankiem śpieszą na jutrznię w bystrzyckim kościele (Kadłubiec, 2000, s. 90).

Analiza utworów potwierdza bogactwo wszystkich wymienionych powyżej tendencji i motywów. Szczegółowe zapoznanie się zastosowanymi środkami muzycznymi jest kluczem do wykonawstwa artystycznego i interpretacji. Cykl Narodziła nam się dobroć jest niezwykle cennym materiałem, który powinien zostać rozpowszechniony na gruncie całej muzycznej, bożonarodzeniowej tradycji, także w zakresie świątecznych koncertów i kolędowania.

\section{Bibliografia}

Bartmiński, J. (2002). Polskie kolędy ludowe. Kraków: Universitas.

Bauman-Szulakowska, J. (2000). Twórczość kompozytorska Stanisława Hadyny.

W: D. Kadłubiec (red.), Stanisław Hadyna - twórca niezwykły. Chorzów: Śląska Fundacja Kultury w Chorzowie.

Hadyna, S. (1989). Droga do hymnu. Warszawa: Instytut Wydawniczy PAX.

Hadyna, S. (2009). Narodziła nam się dobroć. Cykl czternastu kolęd i pastorałek do słów

Kazimierza Szemiotha. Migocz, I. (red.). Koszęcin: Wydawnictwo „Officina Silesia”. Hadyna, S. (1982). W pogoni za wiosnq. Katowice: Wydawnictwo „Śląsk”.

Kadłubiec, D. (2000). Przemówienie nad grobem śp. Stanisława Hadyny. W: Stanisław Hadyna - twórca niezwykły. Chorzów: Śląska Fundacja Kultury w Chorzowie.

Niedoba, A. (2010). Stanisław Hadyna (1919-1999). Wisła: Urząd Miejski w Wiśle.

Marchwica, W. (1996). Właściwości muzyczne kolęd polskich XVI-XVIII w. W: T. Budrewicz, S. Koziara, J. Okoń (red.), Z kolędq przez wieki. Kolędy w Polsce i krajach słowiańskich. Tarnów: „Biblos”.

Ochman, W. (1985). Narodziła nam się dobroć. TK-64, Tonpress.

Podhajski, M. (2005). Kompozytorzy polscy 1918-2000. Gdańsk-Warszawa: Wydawnictwo Akademii Muzycznej im. S. Moniuszki.

Skoczek, T., Załęczny, J., Gmitruk, J. (2017). Z kolędq przez stulecia. Warszawa: Muzeum Niepodległości, Muzeum Historii Polskiego Ruchu Ludowego. 
Szymanderska, H., Szymanderski, W. (1989). Polskie kolędy patriotyczne: 1803 - do dzisiaj. Warszawa: „Epoka”.

Tarnowski, S. (1894). O kolędach. Kraków: Spółka Wydawnicza Polska.

Żabczyc, J. (1998). Symfonije anielskie. A. Karpiński, K. Mrowcewicz, A. Masłowska-Nowak (red.). Warszawa: Instytut Badań Literackich PAN. 